\title{
Hypoglycaemic Effect of the Salt Bush (Atriplex Halimus) - a Feeding Source of the Sand Rat (Psammomys Obesus)
}

\author{
Z. Aharonson, J. Shant (Mtshkinsky) and F.G. Sulmax \\ Department of Applied Pharmacology, School of Pharmacy, Hebrew University, Jerusalem, Israel \\ Received: February 13, 1969
}

Summary. The fact that the so-called "Sand Rat" (Psammomys obesus) is highly susceptible to diabetes, and succumbs to it while changing its food from green leaves to laboratory pellets, puzzled us for a long time. Several hypotheses for this phenomenon were suggested, based on the idea that the sand rats are predisposed to diabetes, and that diabetes occurs when the rats are fed on a high caloric diet. In addition to this, it was noticed that the diabetic rats have high plasma insulin levels, which indicated an impairment in their peripheral utilization of glucose. - Assuming that the green leaves which the sand rats find in nature prevent their becoming diabetic, we examined the main feeding source of the sand rats in Israel for possible hypoglycaemic activity. Press juice from green leaves of Atriplex halimus, as well as their water extract and dialysate, were fed to normal and to alloxan-diabetic albino rats, and showed a significant hypoglycaemic effect without any decrease in appetite. Moreover, their food and water intake was increased by $50-800 \%$ within $5 \mathrm{~h}$ after treatment. The effect was also preserved in the ash of the dialysate. The composition of the hypoglycaemic principle is now under study. It is not based on the presence of cations, since the active extracts contained $\mathrm{K}, \mathrm{Na}, \mathrm{Ca}, \mathrm{Mg}$ and $\mathrm{Al}$ only.

Effet hypoglycémiant d'Atriplex halimus - source principale de nourriture du "rat des sables》 (Psammomys obesus)

Résumé. Le fait que le «rat des sables» soit très sensible au diabète et en meure dès que sa nourriture naturelle de feuilles vertes est remplacée par des comprimés de laboratoire, nous a depuis longtemps intrigués. - Plusieurs hypothèses ont été suggérées, basées essentiellement sur l'idée que les urats des sables» sont prédisposés au diabète, et que la maladie survient dès qu'ils sont soumis à un régime riche en calories. En outre, on avait remarqué que le taux plasmatique d'insuline était élevé chez les rats diabétiques, ce qui signifiait une diminution de l'utilisation périphérique du glucose. - En admettant que les feuilles vertes, trouvées par les "rats des sables» dans la nature, suffisent à prévenir le diabète, nous avons examiné cette principale source de nourriture, en vue d'y déceler une activité hypoglycémiante possible. Nous avons constaté un effet hypoglycémiant très net chez des rats normaux et rendus diabétiques par l'alloxane, nourris de jus pressé de feuilles vertes d'atriplex halimus, ou de leur extrait aqueux, ou du dialysat de cet extrait, et ceci sans réduc- tion de leur appétit. De plus, leur consommation d'eau et de nourriture a été augmentée de $50-800 \%$ dans les $5 \mathrm{~h}$ qui suivirent le traitement. La cendre de ce dialysat s'est montré e également hypogly cémiante. La composition chimique de cette substance hypoglycémiante est actuellement étudiée. Elle ne se base pas sur la présence des cations, car les extraits actifs ne contiennent que du $K$, $\mathrm{Na}, \mathrm{Ca}, \mathrm{Mg}$, et $\mathrm{Al}$.

Hypoglykämischer Effeltt von Atriplex halimus Hauptnahrungsquelle der Sandratte (Psammomys obesus)

Zusammenfassung. Die Tatsache, daß die sogenannte "Sandratte" (Psammomys obesus) leicht zu Diabetes neigt, ist bekannt. Wenn ihr Futter von grünen Blättern auf Laboratoriumspreßlinge umgestellt wird, entwickelt die Sandratte bald einen schweren Diabetes. Verschiedene Hypothesen wurden aufgestellt, die auf der Annahme fußten, daß die Sandratten Diabetes-empfindlich seien und daß dieser Diabetes auftritt, wenn die Ratten auf kalorienreiche Diät gesetzt werden. Dabei wurde festgestellt, daß die diabetischen Sandratten einen hohen Plasma-Insulin-Spiegel entwickeln, was darauf schließen läßt, daß hier eine Beeinträchtigung ihres peripheren GlucoseUtilisationsvermögens vorliegt. - Ausgehend von der Annahme, daß die frischen Blätter, welche die Sandratte in der Natur findet, das Auftreten des Diabetes verhüten könnten, untersuchten wir die Hauptnahrungsquellen dieser Ratte in Israel auf ihre hypoglykämische Aktivität. Normale Ratten und alloxan-diabetische Ratten wurden sowohl mit dem Preßsaft frischer Blätter von Atriplex halimus (Staudenmelde) als auch mit deren wäßrigem Auszug und Dialysat gefüttert. Dabei zeigte sich, daß diese Pflanze eine beachtliche hypoglykämische Wirkung besitzt, ohne den Appetit herabzusetzen. Während der ersten 5 Std nach der Behandlung gingen Wasser- und Nahrungsaufnahme sogar um $50-800 \%$ herauf. Der hypoglykämische Effekt bleibt auch in der Asche des Dialysats erhalten. Das wirksame hypoglykämische Prinzip von Atriplex halimus wird jetzt von uns untersucht. Es hat sicher nichts mit dem Kationengehalt der Extrakte zu tun, die nur K, Na, Ca, Mg und Al enthalten.

Key-words: Hypoglycaemic substances from plants, sand rat, psammomys obesus, atriplex halimus, diabetes mellitus, pancreas, carbohydrate metabolism.

\section{Introduction}

The sand rat (Psammomys obesus) is regarded as a useful animal for studies on experimental diabetes, since diabetes can be easily induced in this animal by changing its diet from fresh vegetables to laboratory chow. Almost all sand rats maintained on a diet of laboratory pellets develop signs of diabetes mellitus, e.g. hyperglycaemia, glucosuria and cataracts. At autopsy these animals show degranulation of the beta-cells of the islets of Langerhans, and those with the most severe diabetes at the time of death show also islet cell vacuolization and glycogen nephrosis. Sand rats that were fed exclusively on fresh vegetables for a similar length of time did not show any of these symptoms, nor did animals when examined immediately after trapping. On the other hand, a high percentage of all rats examined - both normal and diabetic - showed pneumonia and abscesses in the jaws and skull at time of death. There was no apparent difference in the inci- 
dence of involvement between the diabetic group and the group fed vegetables, which was considered to be "non-diabetic". There is general belief that "the sand rats are predisposed to diabetes and the high incidence of infections may be a reflection of this incipient diabetic state" (HACKEL et al., 1965a, 1965 b).

Laboratory-born or captured sand rats were raised on spinach, beets and carrots, as controls, and it was found that these sand rats, too, have a diabetic potential, and that stimuli other than dietary ones can uncover this incipient abnormality. Moreover, HackeL et al. $(1965 \mathrm{~b})$ concluded that in the laboratory the sand rat is highly susceptible to developing diabetes mellitus, this tendency being manifest in sand rats on vegetable diet as well as in those fed laboratory chow. The feeding of laboratory chow or a synthetic diet, however, presents a more severe challenge to the carbohydrateregulating mechanism of the sand rats and results in a more dramatic response than is seen with the vegetable diet.

It seems as if the basic conception being emphasized is that the development of diabetes in this species is

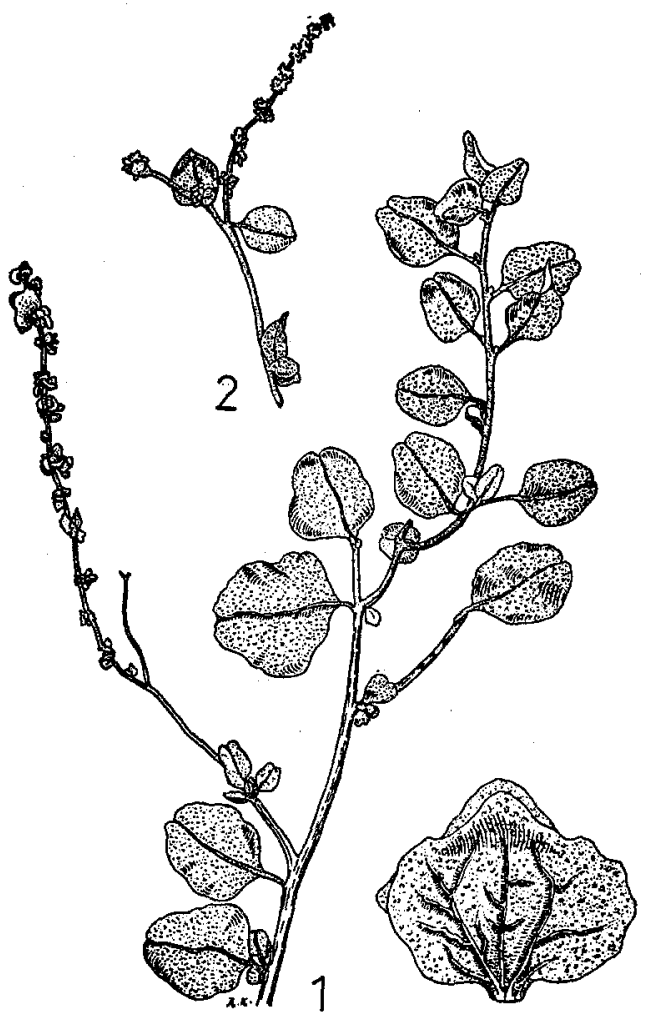

Fig. 1. Atriplex halimus L. (Chenopodiaceae)

Engl.: Tall Shrubby Saltbush

French: Halime, Arroche

Germ. : Staudenmelde,

Hebr.: Maluach Kipeach

(1) Vegetative branch; (2) fruiting branch.

almost certainly due to the intake of a high caloric diet, since no spontaneous diabetes has been shown in sand rats in their natural habitat (SCHMIDT-NIELSEN et al.,
1964; MrKI et al., 1966, 1967; HAINEs et al., 1965; HACKEL et al., 1966).

It occurred to us that the ability of the natural diet of the sand rat to balance carbohydrate metabolism may be due to one of its components, which prevents the highly susceptible animal from developing a severe diabetes. We considered the possibility that the reason for the so-called "spontaneous" diabetes mellitus of these animals in the laboratory was not caused by their being fed on a high caloric diet, but by the absence of a hypothetic protective component in their diet.

We discovered that the main feeding source of the sand rats in our country is Atriplex halimus (Fig. 1), remnants of which were found in their burrows. This induced us to look for its possible hypoglycaemic effect, and to advance a hypothesis for the role it plays in the carbohydrate metabolism of the sand rat.

\section{Materials and Methods}

Leaves of Atriplex halimus were collected in the Dead Sea area during July 1968. The Atriplex juice was squeezed out with a "Hafico" tincture press at a pressure of $400 \mathrm{~kg} / \mathrm{cm}^{2}$, the yield being $50 \mathrm{ml} / \mathrm{kg}$. Water extract was prepared from Atriplex leaves in a Soxhlet apparatus: $180 \mathrm{~g}$ of fresh leaves were cooked for $4 \mathrm{~h}$, and the equivalent of each $\mathrm{ml}$ of the final extract was $1.2 \mathrm{~g}$ of leaves.

Dialysis of the water extract was carried out in a glass jar against distilled water; the process lasted 48 hours with the water being changed every $12 \mathrm{~h}$. The diffusate was concentrated under vacuum, so that from every $100 \mathrm{ml}$ of the water extract $100 \mathrm{ml}$ diffusate was obtained. The dialysis residue (from inside the dialysing tubes) was collected and tested as well.

The diffusate was filtered through cotton, dried. overnight in a drying oven and heated in a furnace for a further $100 \mathrm{~h}$ at $500^{\circ} \mathrm{C}$. Every $100 \mathrm{ml}$ of filtered diffusate yielded about $6 \mathrm{~g}$ of grey ash. Heating the dried diffusate for $36 \mathrm{~h}$ at $700^{\circ} \mathrm{C}$ resulted in a white, partly melted substance, differing in weight from the former ash by about $10 \%$.

The hypoglycaemic effect was studied in 41 normal rats and 500 "alloxan-diabetic" rats, all of them female albino rats of the Hebrew University "Sabra" strain, weighing $100-150 \mathrm{~g}$. The "alloxan-diabetic" rats were subcutaneously injected with alloxan at a dose-level of $20 \mathrm{mg} / 100 \mathrm{~g}$ body weight. Ten days later, blood samples were taken from the tail vein of the rats and tested for glucose by the glucose-oxidase method (HEsTRINLERNER and BEN-YONAF, 1963). Rats with blood glucose levels of $300-500 \mathrm{mg} \%$ were distributed five to a cage, and placed in a temperature-controlled room $\left(25 \pm 1^{\circ} \mathrm{C}\right)$ with neon lighting switched on and off every $12 \mathrm{~h}$. The rats got water and regular laboratory pellets ad libitum. On the morning of the experiment, blood samples were again taken from all the rats and they were then divided into the following groups: 33 rats were fed juice of the leaves, 32 rats received the water 
extract and 23 rats the dialysis residue. Fifty rats were fed five different doses of the diffusate, 34 rats were fed the $500^{\circ}$ and $700^{\circ}$ ashes, and $27 \mathrm{rats}$, which were given saline, served as controls. All feedings were carried out with a stomach tube, and no more than $4 \mathrm{ml}$ was fed at a time. Whenever $8 \mathrm{ml}$ was fed to a rat, a one-hour interval was inserted between both feedings. Food and water intake were recorded for all rats fed the diffusate $(8 \mathrm{ml} / \mathrm{rat})$ and for the saline controls. Further blood samples were taken from each rat 5 and $24 \mathrm{~h}$ after feeding, and their glucose levels tested. Each rat was used for one experiment only. Levels of $\mathrm{Na}^{+}, \mathrm{K}^{+}$and $\mathrm{Cl}^{-}$were determined by routine flame-photometric and titrimetric methods respectively.

\section{Results}

Natural juice and water extract from fresh leaves of Atriplex halimus were found to have a significant hypoglycaemic effect on normal and on diabetic rats. In Table 1 the hypoglycaemic effect of different fractions is compared with the concentrations of $\mathrm{Na}^{+}, \mathrm{K}^{+}$and $\mathrm{Cl}^{-}$measured. The blood glucose level of the healthy rats fed Atriplex dialysate was reduced by $27 \mathrm{mg} \%$ five hours after feeding $(P<0.05)$, and reached the normal level within $24 \mathrm{~h}$.

The blood glucose level of the diabetic rats fed Atriplex halimus juice was reduced by $157 \mathrm{mg} \%, 5 \mathrm{~h}$ after feeding, and of those fed water extract by 118 $\mathrm{mg} \%$; whereas the control diabetic rats, which had been given saline, showed no lowering of their blood glucose level. The significance of this result is very high ( $P<0.02$ for the juice and $P<0.05$ for the water extract), as shown in Table 1.

The hypoglycaemic effect of Atriplex juice and water extract was found to be very profound, though transient, lasting less than $24 \mathrm{~h}$ (Fig. 2). The hypoglycae- mic activity of the water extract passed completely into the dialyzing fluid, which reduced the blood glucose level of the diabetic rats by $127 \mathrm{mg} \%, 5 \mathrm{~h}$ after feeding, leaving the dialysis residue without any hypoglycaemic activity. Exactly the same activity (lowering by $125 \mathrm{mg} \%$ ) was found after feeding the soluble part of the $500^{\circ} \mathrm{C}$ ash, which is a significant result $(P<0.05)$.

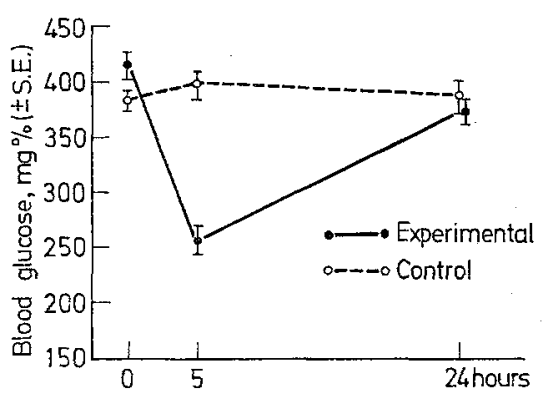

Fig. 2. Hypoglyeaemic effect of Atriplex halimus L. (Chenopodiaceae) -- average of 60 alloxan-diabetic rats after feeding each rat with juice of $150 \mathrm{~g}$ leaves or with saline

Most of the hypoglycaemic effect disappeared when the soluble part of the $700^{\circ} \mathrm{C}$ ash was tested. The validity of the dialysis could be judged from the values of $\mathrm{Na}^{+}$, $\mathrm{K}^{+}$and $\mathrm{Cl}^{-}$tested in the dialysate.

Food and water intake were recorded for all rats (normal and diabetic) fed the diffusate, and for the saline controls; but in no case could any reduction in appetite be observed. Indeed, food and water consumption of the diabetic rats rose by 50 and 200 percent, and those of the normal rats by 300 and 800 percent respectively, $5 \mathrm{~h}$ after feeding. These differences disappeared within $24 \mathrm{~h}$.

Table 1. Hypoglycaemic effect of Atriplex halimus preparations in normal and in alloxan-diabetic rats

\begin{tabular}{|c|c|c|c|c|c|c|c|c|}
\hline \multirow[t]{2}{*}{ Feeding material } & \multirow{2}{*}{$\begin{array}{l}\text { No. of } \\
\text { rats } \\
\text { tested }\end{array}$} & \multirow{2}{*}{$\begin{array}{l}\text { Extract } \\
\text { fed to } \\
\text { rats } m l\end{array}$} & \multicolumn{3}{|c|}{ meq/litre } & \multicolumn{3}{|c|}{ Blood glucose levels ${ }^{a}$} \\
\hline & & & $\mathrm{Na}^{+}$ & $\mathrm{K}^{+}$ & $\mathrm{Cl}^{-}$ & $0 \mathrm{~h}$ & $5 \mathrm{~h}$ & $24 \mathrm{~h}$ \\
\hline $\begin{array}{l}\text { Normal rats } \\
\text { Diffusate } \\
\text { Control (Saline) } \\
\end{array}$ & $\begin{array}{l}21 \\
20\end{array}$ & $\begin{array}{l}8 \\
8\end{array}$ & $\begin{array}{c}1130 \\
- \\
\end{array}$ & $\begin{array}{r}268 \\
- \\
\end{array}$ & $\begin{array}{l}950 \\
- \\
\end{array}$ & $\begin{array}{l}81 \pm 6 \\
80 \pm 4 \\
\end{array}$ & $\begin{array}{l}54 \pm 7 \\
73 \pm 3 \\
\end{array}$ & $\begin{array}{l}88 \pm 3 \\
80 \pm 2 \\
\end{array}$ \\
\hline $\begin{array}{l}\text { Alloxan-diabetic rats } \\
\text { Leaf juice } \\
\text { Water extract } \\
\text { dialysis residue } \\
\text { diffusate } \\
\text { diffusate } \\
\text { diffusate } \\
\text { diffusate } \\
\text { diffusate }\end{array}$ & $\begin{array}{l}33 \\
32 \\
23 \\
10 \\
10 \\
10 \\
10 \\
10\end{array}$ & $\begin{array}{l}7.5 \\
8 \\
8 \\
1 \\
2 \\
4 \\
8 \\
16\end{array}$ & $\begin{array}{r}1580 \\
1400 \\
60 \\
1130 \\
1130 \\
1130 \\
1130 \\
1130\end{array}$ & $\begin{array}{r}320 \\
300 \\
12 \\
268 \\
268 \\
268 \\
268 \\
268\end{array}$ & $\begin{array}{r}1515 \\
1440 \\
10 \\
950 \\
950 \\
950 \\
950 \\
950\end{array}$ & $\begin{array}{l}414 \pm 12 \\
339 \pm 14 \\
344 \pm 14 \\
356 \pm 39 \\
361 \pm 24 \\
372 \pm 29 \\
397 \pm 15 \\
371 \pm 19\end{array}$ & $\begin{array}{l}257 \pm 12 \\
221 \pm 12 \\
330 \pm 12 \\
305 \pm 36 \\
331 \pm 39 \\
340 \pm 37 \\
270 \pm 25 \\
214 \pm 27\end{array}$ & $\begin{array}{l}372 \pm 9 \\
374 \pm 17 \\
318 \pm 15 \\
290 \pm 38 \\
307 \pm 23 \\
303 \pm 29 \\
411 \pm 11 \\
321 \pm 25\end{array}$ \\
\hline $\begin{array}{l}\text { Ash }\left(500^{\circ} \mathrm{C} / 100 \mathrm{~h}\right) \\
\text { dissolved at } 100^{\circ} \mathrm{C} \\
\text { Ash }\left(700^{\circ} \mathrm{C} / 36 \mathrm{~h}\right) \text { do } \\
\text { Control (saline) }\end{array}$ & $\begin{array}{l}17 \\
17 \\
27\end{array}$ & $\begin{array}{l}8 \\
8 \\
8\end{array}$ & $\begin{array}{l}982 \\
907 \\
-\end{array}$ & $\begin{array}{c}253 \\
233 \\
-\end{array}$ & $\begin{array}{l}900 \\
850 \\
-\end{array}$ & $\begin{array}{l}357 \pm 11 \\
392 \pm 17 \\
383 \pm 9\end{array}$ & $\begin{array}{l}232 \pm 15 \\
349 \pm 19 \\
398 \pm 11\end{array}$ & $\begin{array}{l}308 \pm 23 \\
410 \pm 12 \\
386 \pm 13\end{array}$ \\
\hline
\end{tabular}

a Mean \pm S.E. 


\section{Discussion}

Atriplex halimus L. (Chenopodiaceae; Eng.: Tall shrubby saltbush; French: Halime, Arroche; German: Staudenmelde; Hebrew: Maluach kipeach) is a branched, woody shrub with vesicular hairs, erect stem and silvery-white leaves, up to $3 \mathrm{~cm}$ long, and short petioled. It is a halophytic plant, and common habitant of salines, wadi beds and sandy soils. In Israel it grows in the lower Jordan Valley, Dead Sea area, Arava valley, Moab and Edom. It is also spread over the Mediterranean region, North Africa and Southern Europe. Atriplex halimus is especially common in inundated saline depressions, and around oases of the Jordan valley. It is a rather palatable browse shrub. The leaves are sometimes eaten by hungry shepherds; the salt content of the leaves increases with the aridity of the habitat, and makes the plant less palatable (ZOHARY, 1966).

Atriplex halimus is rich in protein, sufficient to meet the feeding requirements of both cattle and sheep (EspLIN et al., 1937). Atriplex halimus is also a source of Vitamins $\mathrm{A}, \mathrm{C}$ and $\mathrm{D}$, and was suggested among other wild plants as a supplementary source for these vitamins (BELENKII and SaKHaRova, 1939; HaRET, 1947). The most striking fact is the high content of mineral in this plant, containing $\mathrm{Na}_{2} \mathrm{O}(10.79 \%), \mathrm{MgO}$ $(2.20 \%), \mathrm{SiO}_{2}(2.16 \%), \mathrm{CaO}$ and $\mathrm{K}_{2} \mathrm{O}(1.89 \%$ each) and $\mathrm{Cl}^{-}(11.72 \%)$ (TeakLE, 1935). In the juice extracted in our laboratory we also found high values of $\mathrm{Na}^{+}$ (1580 meq/l), $\mathrm{K}^{+}(320 \mathrm{meq} / \mathrm{l})$ and $\mathrm{Cl}^{-}(1515 \mathrm{meq} / \mathrm{l})$.

The severe diabetic state of the sand rat, when shifted from Atriplex halimus to laboratory chow, made scientists look for the missing link between the Atriplex content and carbohydrate metabolism in the rat. It was already noted by DE Fronzo et al. (1967) that, since plasma insulin levels can be remarkably high in diabetic sand rats, it is not likely that the primary defect is one of insufficient production of insulin by the pancreas but rather an interference with peripheral utilization of insulin. Superimposed on this picture, however, there may be a terminal loss of pancreatic reserve resulting in a deficiency in insulin production. In addition, it has been shown that also in normoglycaemic sand rats, fed Purina Lab-Chow ad libitum and fresh vegetables daily, the adipose tissue showed in vitro decreased insulin uptake (De Fronzo, 1967). Testing our hypoglycaemic extracts in captive sand rats was impossible as their hyperglycaemic condition is not consistent, and breeding these animals for laboratory purposes is only in its incipient stage (PRANGE et al., 1968).

The definite hypoglycaemic effect exerted by the Atriplex juice on normal as well as on diabetic rats, made us postulate that the Atriplex contains some hypoglycaemic agent. Such an agent could naturally be one of the many hypoglycaemic principles found in plants, but some correlation between the high salt content of the plant and its hypoglycaemic effect could not $a$ priori be eliminated. Chemical analysis of an Atriplex halimus extract which was dried at $500^{\circ} \mathrm{C}$ for $100 \mathrm{~h}$ revealed the presence of $\mathrm{K}, \mathrm{Na}, \mathrm{Ca}, \mathrm{Mg}$ and $\mathrm{Al}$ only. The following cations could not be detected $(<1000$ p.p.m.): $\mathrm{Cr}, \mathrm{Ni}, \mathrm{Cu}, \mathrm{Bi}, \mathrm{Fe}, \mathrm{Ra}, \mathrm{Hg}, \mathrm{Ba}, \mathrm{Sr}, \mathrm{Cd}, \mathrm{Sb}, \mathrm{Zn}$, $\mathrm{Ag}, \mathrm{Pb}, \mathrm{Mn}$, Si.

The view that the normal rapid release of insulin from the pancreas in response to a glucose load is somehow potassium-dependent was advanced by ConN (1965) and others (GARDNER et al., 1950; FUHRMAN, 1951). It was suggested that insulin release was dependent on a specific concentration of $\mathrm{K}^{+}$ions within the cells. This phenomenon may also be related to the concentration of sodium ions in blood, as it was found that in sheep grazing salt-bush, plasma sodium concentration was inversely related to their water turnover (MacFarLane et al., 1967). No interpretation can ignore the fact that the hypoglycaemic effect of Atriplex was obtained in alloxan-diabetic rats, whose beta-cells were severely destroyed. This points towards a peripheral impairment of insulin activity elicited by the plant extract. Both views are probable and require further investigation.

Quantitative analyses of the Atriplex extract and diffusate are now being carried out. This may enable us to test the hypoglycaemic effect of salt solutions comparable with, or equivalent to the Atriplex extracts.

Acknowledgement. The authors acknowledge the advice of Dr. S. Dikstein, the devoted assistance of Mr. B. JosEPH and the botanical classification by Dr. A. DANIN. Fig. 2 was reproduced from Flora Palaestinae Vol. I (1966) with the kind permission of Prof. M. Zohary.

\section{References}

Betenkm, N., and E. SAkHaRova: Orach as a source of Vitamin A. Sovet. Ptitsevodstva No. 5, $27-28$ (1939); Khim. Referat Zhur. No. 12, 40 (1939).

Cons, J.W.: Hypertension, the potassium ion and impaired carbohydrate tolerance. New Engl. J. Med. 273, $1135-1143(1965)$.

De Fronzo, R., E. Mrki, and J. Steinke: Diabetic syndrome in sand rats. (III) Observation on adipose tissue and liver in the non-diabetic stage. Diabetologia 3, $140-142(1967)$.

Esplin, A.C., J.E. Greaves, and L.A. Stoddart: Composition of forage plants and use of supplements (on Utah's winter range). Utah Agr. Expt. Sta., Bull. 277, $4-48$ (1937).

FunRmax, F.A.: Glycogen, glucose tolerance and tissue metabolism in potassium-deficient rats. Amer. J. Physiol. 167, 314-320 (1951).

Gardner, L.I., N.B. Talbot, C.D. Cook, H. Berman, and U.R. ConCEPCION: Effect of potassium deficiency on carbohydrate metabolism. J. Lab. clin. Med. 35, $592-602(1950)$.

HaCkEL, D.B., K. SchmidT-Niensen, H.B. Hamnas, and E. Mikat: Diabetes mellitus in the sand rat (Psammomys obesus). Lab. Invest. 14, 200-207 (1965a).

- A.L. Frohman, E. Mrkat, M.E. Lebovitz, K. SchmidTNIELSEN, and T.D. KINNEY: Review of current studies in effect of diet on glucose tolerance of the sand rat (Psammomys obesus). Ann. N.Y. Acad. Sci. 131, 459$463(1965 \mathrm{~b})$. 
- - - - - Effect of diet on the glucose tolerance and plasma insulin levels of the sand rat (Psammomys obesus). Diabetes 15, 105-114 (1966).

Haines, H.B., D.B. HaCKer, and K. Schmidt-Nimesen : Experimental diabetes mellitus induced by diet in the sand rat. Amer. J. Physiol. 208, 297 -300 (1965).

HAREI, A.N.: Utilization of wildly growing edible plants as means of counteracting avitaminoses $A$ and $D$. Meditsin. Sestra No. 6, 25-26 (1947).

HESTRIN-LERNER, S., and S. BEN-YONAH: Routine determination of blood-glucose with glucose oxidase. Bull. Res. Council. Israel 10E, 188 (1963).

Macfarlane, W.V., B. Howard, and B.D. Siebert Water metabolism of Merino and border Leicester sheep grazing saltbush. Aust. J. Agric. Res. 18, 947-958 (1967).

Mrki, E., A.A. LtKw, J.S. Soetoner, J. Steinke, and G.F. CAHILL Jr.: Acute ketotic-type diabetic syndrome in sand rats (Psammomys obesus) with special reference to the pancreas. Metabolism 15, 149-160 (1966).
- - J. Steinke, and J.S. Somsdrer: Diabetic syndrome in sand rats. (II) Variability and association with diet. Diabetologia 3, 135-139 (1967).

Prange, H.D., K. Schmidt-Nielsen, and D.B. Hadkel Care and breeding of the fat sand rat (Psammomys obesus Cretzschmar). Lab. Animal Care 18, 170-179 (1968).

Sohmidt-Nielsen, K., H.B. Haines, and D.B. Hacket: Diabetes mellitus in sand rats induced by standard laboratory diets. Science 143, 689-690 (1963).

TEAKLE, L.J.H.: The chemical composition of salt bushes from the Salmon Gums area. J. Dept. Agr. Western Australia (2) 12, 188 - 189 (1935).

ZoHARY, M.: Flora Palaestinae. Jerusalem: The Israel Academy of Science and Humanistics Publ. 1966.

Prof. Dr. F.G. Sulman

The Hebrew University of Jerusalem

Department of Applied Pharmacology Jerusalem, Israel 